\title{
II. MAN AND BIOSPHERE
}

\section{FIRE SEVERITY ASSESSMENT USING NDVI DERIVED FROM LANDSAT TM/ETM IMAGES AND TERRAIN DATA}

\author{
Ibrahim Molla, Emiliya Velizarova, Mariana Zaharinova
}

\begin{abstract}
The forest fires influence on the plants and soil depends on the fire severity and time of exposure. Fire severity integrates physical, chemical and biological changes occurring in ecosystems on the area as a consequence of fire influence. The purpose of the current investigation was to examine the role of the forest fire severity on the vegetation cover of the area of Svilengrad Municipality, using NDVI (Normalized Difference Vegetation Index) before fire and after fire, derived from LANDSAT $8 \mathrm{TM} / \mathrm{ETM}$ images. The comparison of the data from NDVI and that observed on the terrain data was also targeted. The results show that NDVI are changed significantly in fire affected area depending on vegetation cover and type of fire. This index also is very sensitive to changes during time after fire occurrence. One year after fire occurrence the NDVI values increased to $+0.305(0.048)$ for whole studied area. Through dNDVI could be distinguish the recovery rates of the fire affected areas with different tree species.
\end{abstract}

Key words: fire severity, Sakar mountain, NDVI, tree species

\section{INTRODUCTION}

The forest fire effects on plant and soil vary depending on the fire intensity and time of exposure [1]. Fire severity integrates physical, chemical and biological changes occurring on the area as a consequence of fire influence [2,3,4,5]. Fire also has important and immediate effects on soil properties. More affected layers are usually surface ones, while as deeper the horizon, as the temperature is lower [6]. This effect may reduce plant regeneration response [7].

Landsat satellite images have been used quite early for analysis of forest fires influence. Thus, [8] used Landsat MSS images for classification and estimation of the fire-ravaged areas of Japan and Kritikos (1992) applied supervised and unsupervised classification for assessing the fire damage at Mount Athos in Greece.

A near-infrared / red ratio image might be useful for differentiating between areas with stressed and nonstressed vegetation. Various mathematical combinations of satellite bands, have been found to be sensitive indicators of the presence and condition of green vegetation. These band combinations are thus referred to as vegetation indices. There are based on the reflectance properties of vegetated areas as compared to clouds, water and snow on the one hand, and rocks and bare soil on the other. Vegetated areas have a relatively high reflection in the near-infrared and a low reflection in the visible range of the spectrum. Clouds, water and snow have larger visual than near-infrared reflectance. Rock and bare soil have similar reflectance in both spectral bands. Green vegetation yields high values for the index. In contrast, the water yields negative values and bare soil gives indices near zero [9].
The Normalized Difference Vegetation Index (NDVI) is an index ranging from -1.0 to 1.0. NDVI of a dense vegetation canopy will tend to positive values (from 0.3 to 0.8 ), while clouds and snow fields will be characterized by negative values of this index. The water areas (e.g., oceans, seas, lakes and rivers) have a rather low reflectance in both spectral bands (at least away from shores) and thus the NDVI values are very low positive or even slightly negative. The soil, in general, exhibit a near-infrared spectral reflectance somewhat larger than the red, and thus tend also to generate rather small positive NDVI values (from 0.1 to 0.2$)$. Very low values of NDVI (0.1 and lower) correspond to the barren areas of rock, sand, or snow. Moderate values represent shrub and grassland (from 0.2 to 0.3 ), while the temperate and tropical rainforests show the high values (from 0.6 to 0.8 ) [10].

The purpose of the current investigation was to examine the role of the forest fire severity on the vegetation cover of the area of Svilengrad Municipality, using NDVI before fire and after fire, derived from LANDSAT $8 \mathrm{TM} / \mathrm{ETM}$ images. The comparison of the data from NDVI and that observed on the terrain data was also targeted.

\section{STUDIED AREA}

The studied area (about 1280 ha) situates within the Svilengrad Municipality (south-east of Bulgaria) area and was affected by fire in July and in August 2013. The forest fire on the territory of the TD SFE "Svilengrad" near to Ravna gora village started on 22.08.2013 and was active till 30.08.2013.

On the Fig. 1 the polygon of the fire affected area in Svilengrad Municipality (south-east Bulgaria) and 
sampling sites are shown. The altitude of the territory varies from 300 to $540 \mathrm{~m}$ a.s.l. The forest fire affected different tree species, shrubs and grasses. We studied the changes in area covered with Scots pine plantation and coppice oak stand as described in Table 1 and Table 3.

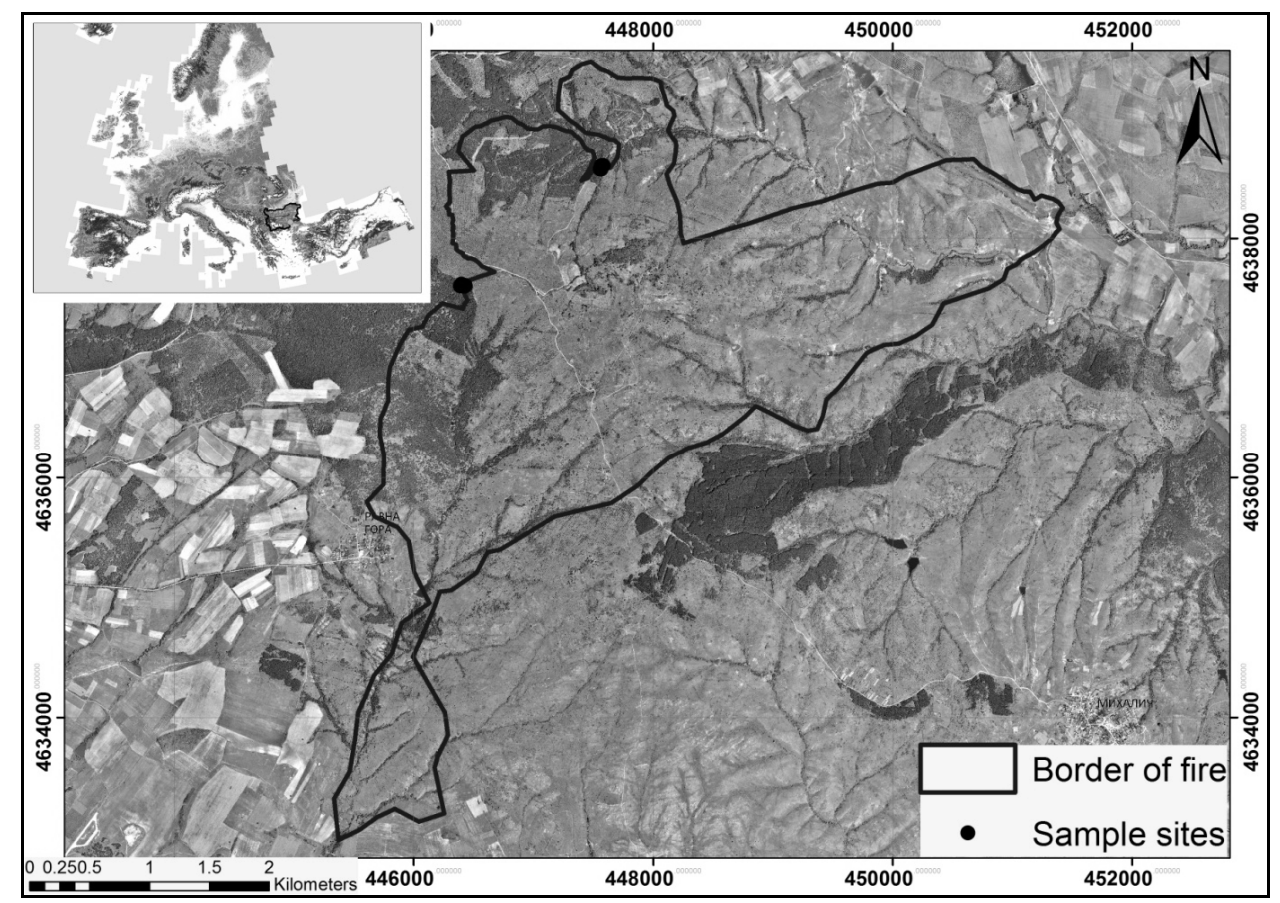

Fig. 1. Area affected by fire within territory of the Svilengrad Municipality and samples sites $(\cdot)$.

Table. 1. Characteristic of sampling areas

\begin{tabular}{|c|c|c|c|c|c|c|c|}
\hline $\begin{array}{l}\text { Studied } \\
\text { objects }\end{array}$ & Variants & Fire type & $\begin{array}{c}\text { Dominant tree } \\
\text { species }\end{array}$ & $\begin{array}{l}\text { Altitude } \\
\text { (m a.s.l.) }\end{array}$ & $\begin{array}{l}\text { Tree } \\
\text { age }\end{array}$ & $\begin{array}{c}\text { Area } \\
\text { (ha) }\end{array}$ & $\begin{array}{l}\text { UTM } 35 \text { zone } \\
\text { Geodesic } \\
\text { projection }\end{array}$ \\
\hline \multicolumn{8}{|c|}{ Svilengrad Municipality } \\
\hline \multirow{3}{*}{1} & S1 & \multirow{3}{*}{ Surface fire } & \multirow{3}{*}{$\begin{array}{c}\text { Quercus } \\
\text { pubescens Wild. }\end{array}$} & \multirow{3}{*}{462} & \multirow{3}{*}{50} & \multirow{3}{*}{5.8} & $\begin{array}{r}4637601.964 \mathrm{~N} \\
446423.862 \mathrm{E} \\
\end{array}$ \\
\hline & S2 & & & & & & $\begin{array}{c}4637608.84 \mathrm{~N} \\
446422.18 \mathrm{E}\end{array}$ \\
\hline & S3 & & & & & & $\begin{array}{c}4637606.964 \mathrm{~N} \\
446431.361 \mathrm{E}\end{array}$ \\
\hline \multirow{3}{*}{2} & S4 & \multirow{3}{*}{ Surface fire } & \multirow{3}{*}{$\begin{array}{c}\text { Pinus sylvestris } \\
\text { L. }\end{array}$} & \multirow{3}{*}{378} & \multirow{3}{*}{45} & \multirow{3}{*}{1.2} & $\begin{array}{l}4638583.24 \mathrm{~N} \\
447562.4 \mathrm{E}\end{array}$ \\
\hline & S5 & & & & & & $\begin{array}{c}4638576.45 \mathrm{~N} \\
447565.13 \mathrm{E}\end{array}$ \\
\hline & S6 & & & & & & $\begin{array}{r}4638577.02 \mathrm{~N} \\
447557.42 \mathrm{E}\end{array}$ \\
\hline
\end{tabular}

\section{METHODS}

\subsection{Data sources for images}

A set of Landsat 8 TM images (with 11 spectral bands and $30 \mathrm{~m}$ spatial resolution) with data before and immediately after the forest fire occurrence have been used. Four images were acquired in the same season in order to minimize the impact of vegetation at different seasons (Table 2). High resolution images from 2006, terrain data from two sampling sites of the area, affected by fire and reports about forest fires, issued by State Forestry Enterprises (SFE) "Svilengrad" have been used. 
Table 2 Characteristic of the used images

\begin{tabular}{|c|c|c|c|}
\hline \multirow{2}{*}{ Fire affected area } & \multirow{2}{*}{$\begin{array}{l}\text { Data of fire } \\
\text { occurrence }\end{array}$} & \multicolumn{2}{|c|}{ Date of used images } \\
\cline { 3 - 4 } Svilengrad & & Before fire & After fire \\
\hline \multirow{2}{*}{$22 / 08 / 2013$} & \multirow{2}{*}{$13 / 08 / 2013$} & $14 / 09 / 2013$ \\
\cline { 3 - 4 } & & & $16 / 10 / 2013$ \\
\hline
\end{tabular}

In Table 2, the dates of images from different scenes before and after fire occurrence are presented. Four scenes - one before the fire occurrence and three after fire suppression have been used. From the available scenes after fire suppression have been used that, closest to the date of the fire - 16.10.2013, which was without clouds. The scene from 14.09.2013 has been used just in case for area $A_{\text {F.sylvastrir } 2 \text {. and }}$ A Q.Pubescenswilla., described in Table 3.

\subsection{Calculations}

The Normalized Difference Vegetation Index (NDVI) and difference NDVI (dNDVI) were used for assessment of the vegetation response to the forest fire. NDVI is one of the most well-known, and most frequently used vegetation indices [11, 12].
NDVI indicates the amount of green vegetation presented within a pixel. It is defined by the following equation:

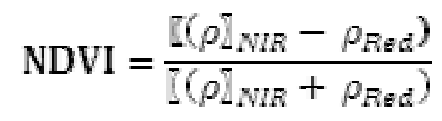

where NDVI - Normalized Difference Vegetation Index, $\rho_{\mathrm{NIR}}$ and $\rho_{\text {Red }}$ indicate the reflectance of the near-infrared and red bands, respectively.

\section{RESULTS AND DISCUSSION}

The image A, on Fig. 2 illustrates low NDVI index, which suppose the earlier damage of the forest vegetation by fire (on 22.03.2013).
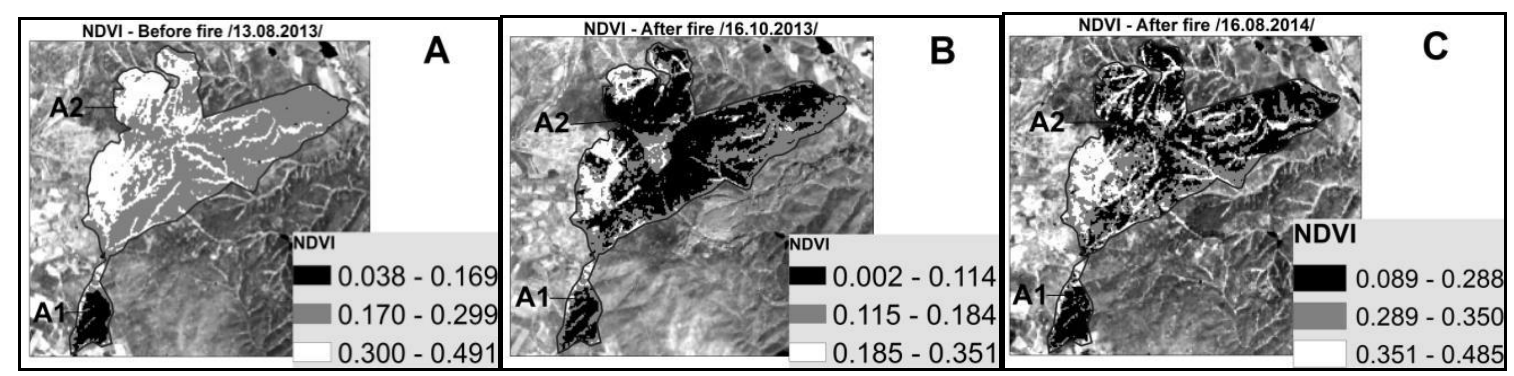

Fig.2. NDVI before fire 13.08.2013 (A) and after fire - 16.10.2013 (B) and 16.08.2014 (C).

On site we collected samples from soil, needles and leaves from Scots pine plantation and coppice oak stand. The forest fire affected 1.2 ha within Scots pine plantation (Table 3). This area was influenced by surface fire, which damages reached to $1.0 \mathrm{~m}$ in height of stand's stems. Moreover, the forest litter was completely burned. The area covered with coppice oak stand, affected by forest fire was $5.8 \mathrm{ha}$. The flame of the fire reached to $1.0-$ $1.5 \mathrm{~m}$ in height of stems. The forest litter of this stand was also completely burned. However there were area with little or no influenced by fire.

The area, affected by fire was not homogeneous, which can be seen from the image from 2006 with a high resolution (Fig. 1). A part of area was covered with tree vegetation, the rest part with grass and shrub vegetation. This corresponds with data acquired from remote sensing as can be seen from data in Table 4 .

The NDVI values of the territory A2, before the fire occurrence vary from $0.170-0.299$ (Fig. $2 \mathrm{~A}$ ) and correspond to the area covered with grass and shrubs which can be seen from Fig. 1. The area covered with tree vegetation show NDVI values up to 0.491 . The mean value for this territory is $0.273( \pm 0.077)$. The Landsat $8 \mathrm{TM}$ image which we used is acquired for nine days before fire, period in which because of the high air temperature and lack of moisture, the vegetation have lower vitality. Nonetheless the clear differences between NDVI values before and after fire could be seen. On the image of Fig. 2 - could be seen the territory previously (from $11.07 \quad 2013$ to 20.07.2013) affected by forest fire. 
Table 3. Area affected by fire

\begin{tabular}{|c|c|}
\hline \multicolumn{2}{|r|}{ Area influenced by fire } \\
\hline A & Total area -1280 ha \\
\hline $\mathrm{A} 1$ & Area affected by fire from 11.07 to $20.07 .2013-72$ ha \\
\hline $\mathrm{A} 2$ & Area affected by fire from $22.08 .2013-1208$ ha \\
\hline A P.SWhanti L. & $\begin{array}{l}\text { Plantation of Pinus Sylvestris } L \text {. affected by surface fire and } \\
\text { damages of stem to } 1 \mathrm{~m} \text { in height }-1.2 \text { ha. }\end{array}$ \\
\hline A Q.PubaguensWilla. & $\begin{array}{l}\text { Mixed coppice oak stand with dominant tree species of Quercus } \\
\text { pubescens Willd. affected by surface fire with stems damages to } \\
1.0-1.5 \mathrm{~m} \text { of height }-5.8 \text { ha. }\end{array}$ \\
\hline
\end{tabular}

On the image of Fig. 2 B, NDVI values for post fire A2 territory, which was the most affected by fire, vary from 0.002 to 0.115 and almost all area is black coloured. These values correspond to the bare soil. We can see that on the area covered with tree species before forest fire occurrence, the NDVI values were the highest - from 0.300 to 0.491 . Two months after fire for some parts of these sites, NDVI values vary from $0.002-0.114$. Obviously, the fire severity was the highest on these sites, in result of which the vegetation was completely burned. On the images these area were coloured in black. For the grey coloured area, the NDVI values vary between $0.115-$ 0.184 , which means the medium fire severity impact.
One year after forest fire, the mean value of NDVI is $0.305( \pm 0.048)$ (Table 4). This increase could be due to the fact that herbaceous were recovered on the almost all area of fire disturbance. On the territory, covered with tree species, a year after fire, the NDVI values vary between 0.089 0.288 which means that this area is not recovered yet.

The strongest impacted forest by fire were coniferous plantation. On the Figure $2 \mathrm{C}$, the white coloured area on the image, exhibits NDVI values from 0.351 to 0.485 . This part of area was covered with deciduous forest, destroyed partly - only on the borderline of the forest fire.

Table 4. Data for NDVI - for total are, influenced by fire

\begin{tabular}{cccc}
\hline \multicolumn{4}{c}{ Total area influenced by fire } \\
\hline $\begin{array}{l}\text { Statistical } \\
\text { parameters }\end{array}$ & NDVI before fire & NDVI After fire & NDVI After fire \\
\hline Mean $( \pm$ SD) & $+0.273(0.077)$ & $/ \mathbf{1 6 . 1 0 . 2 0 1 3} /$ & $+0.305(0.048)$ \\
\hline Min & +0.038 & $+0.124(0.048)$ & +0.089 \\
\hline Max & +0.491 & +0.002 & +0.485 \\
\hline
\end{tabular}

On Fig. 3, the values of NDVI, extracted from pixels before fire event - 13/08/2013 with that NDVI after fire 16/10/2013, 16/08/2014 were compared.

As could be seen the prevailing part of NDVI values extracted from pixels of images before fire exceeds 0.2 . Only for area A1, affected by fire from 11.07 to 20.07.2013, the NDVI values are lower 0.1 Figure 3 (a). A successful recovery of grass cover on both areas - A1 and A2 could be observed one year after fire. On the Fig. 3 (b) the values of pixels are higher than that before fire (0.2).

A better understanding of the fire severity and changes occurred after forest fire give dNDVI (Fig. 4). The high values of this index show the places with the most significant alterations provoked by fire. These significant changes are on the places covered with tree species.

As could be seen on Fig. 5, two months after a fire, affected the territory, designated by A2, the values of dNDVI from all pixels are positive, which proves the forest fire impact. Only on the territory A1, earlier affected by forest fire the values of pixels are negative. One year after forest fire occurrence, there are positive and negative values of dNDVI extracted from pixels of the fire affected territory. A detail study confirms that area, with completely destroyed tree species have positive dNDVI values. 

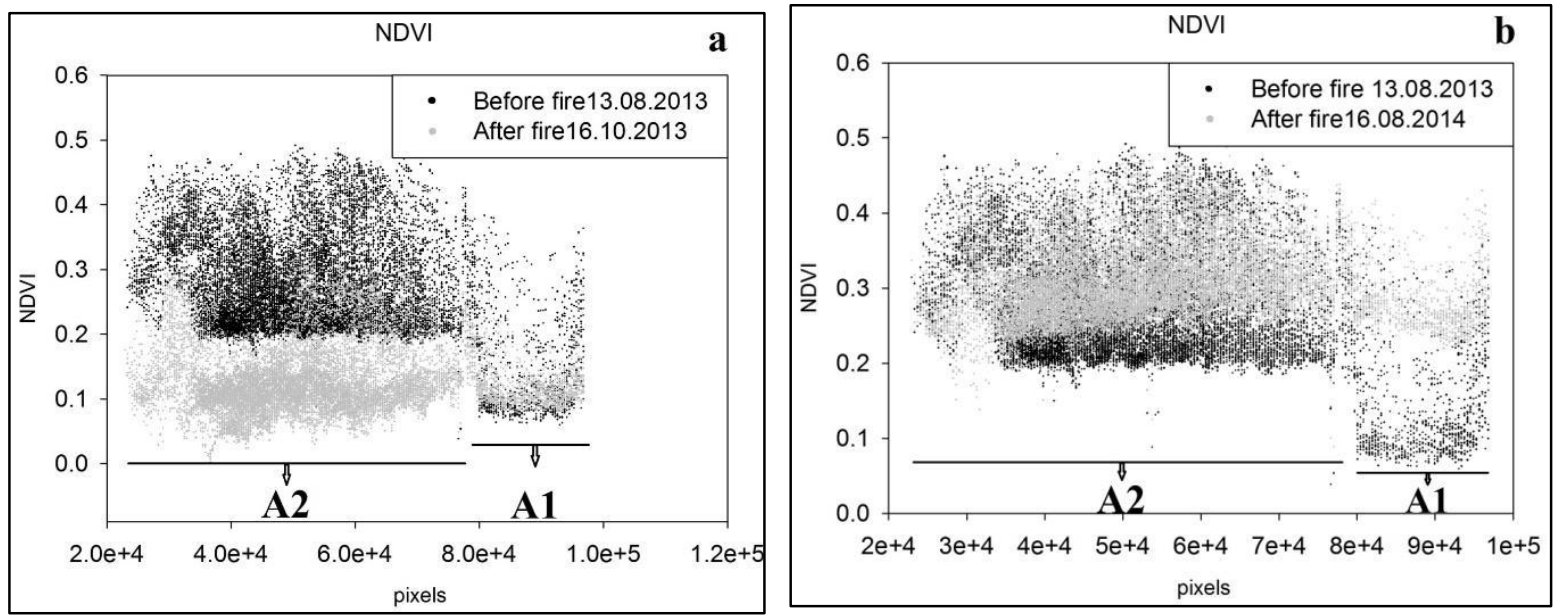

Fig. 3. Values of NDVI, extracted from pixels before fire (13.08.2013) compared with values two months after fire (16.10.2013) (a) and one year after fire (16.08.2014) (b).

Table 5. Data for dNDVI - for total area influenced by fire

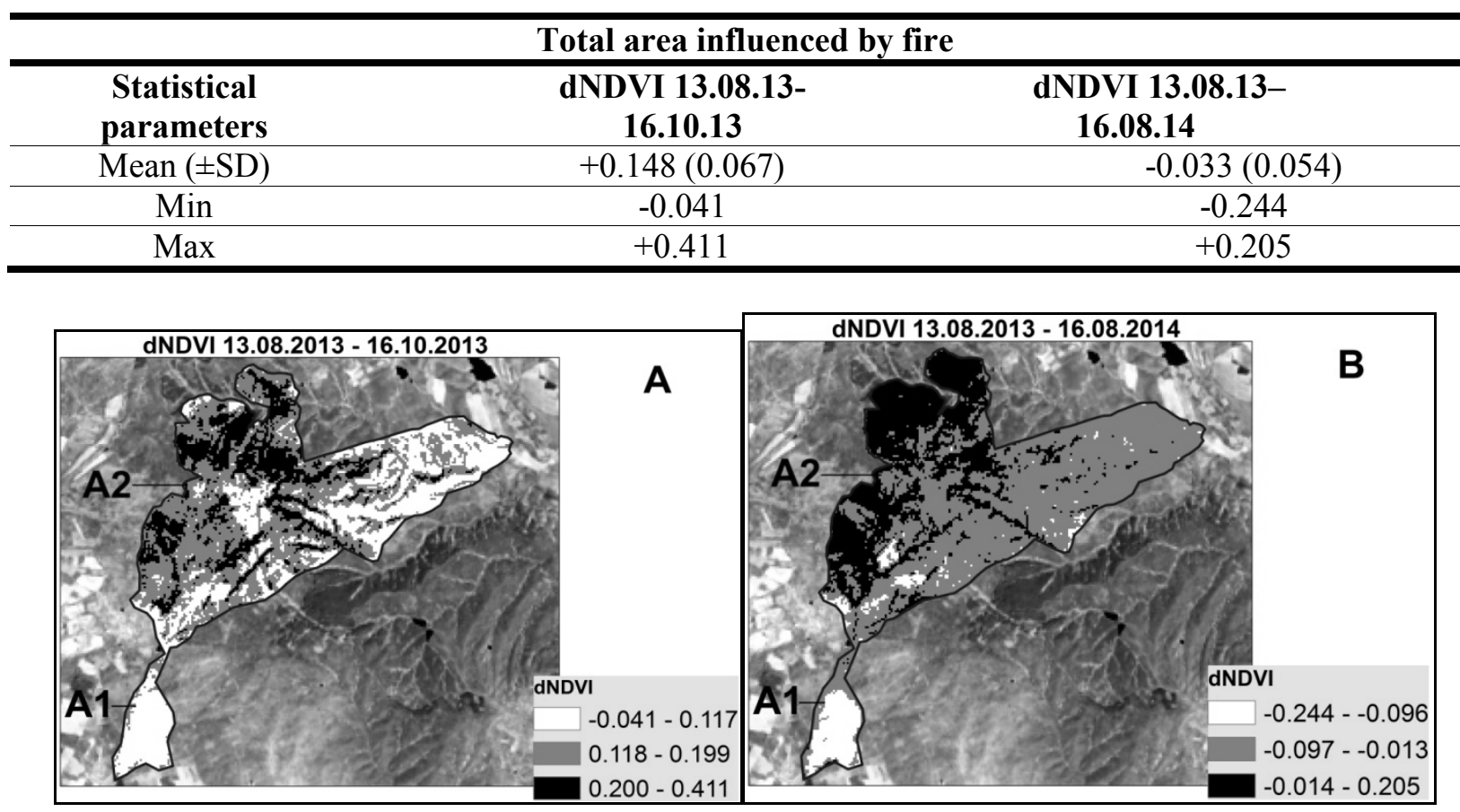

Fig.4. Images for dNDVI for total fire affected area.

In the case with Scots pine plantation the mean value of NDVI value before fire was 0.367 , and decreased to 0,308 one month after forest fire occurrence. Two months later, the mean value of NDVI is -0.209 . A year after the forest fire, the NDVI values were kept low. There is an insignificantly increase of mean value of NDVI, most probably in result of pixels reflecting availability of broadleaf vegetation from unaffected by the forest fire area (Fig. 6).

The picture taken from the unaffected by forest fire part of plantation, picture 2 - six day after surface fire event, and 3 - one year after fire. Images above corresponds to time of pictures

The data for dNDVI values demonstrates the significant changes of the forest cover two months after fire. These changes were kept a year after fire (Table 7).

Mean values of the NDVI of the are occupied with Quercus pubescence Willd stands also have low value 0.225 in comparison with that before fire - 0.415 (Table 6). The oak stand was most affected in the places where there was dry grass below tree canopy. 

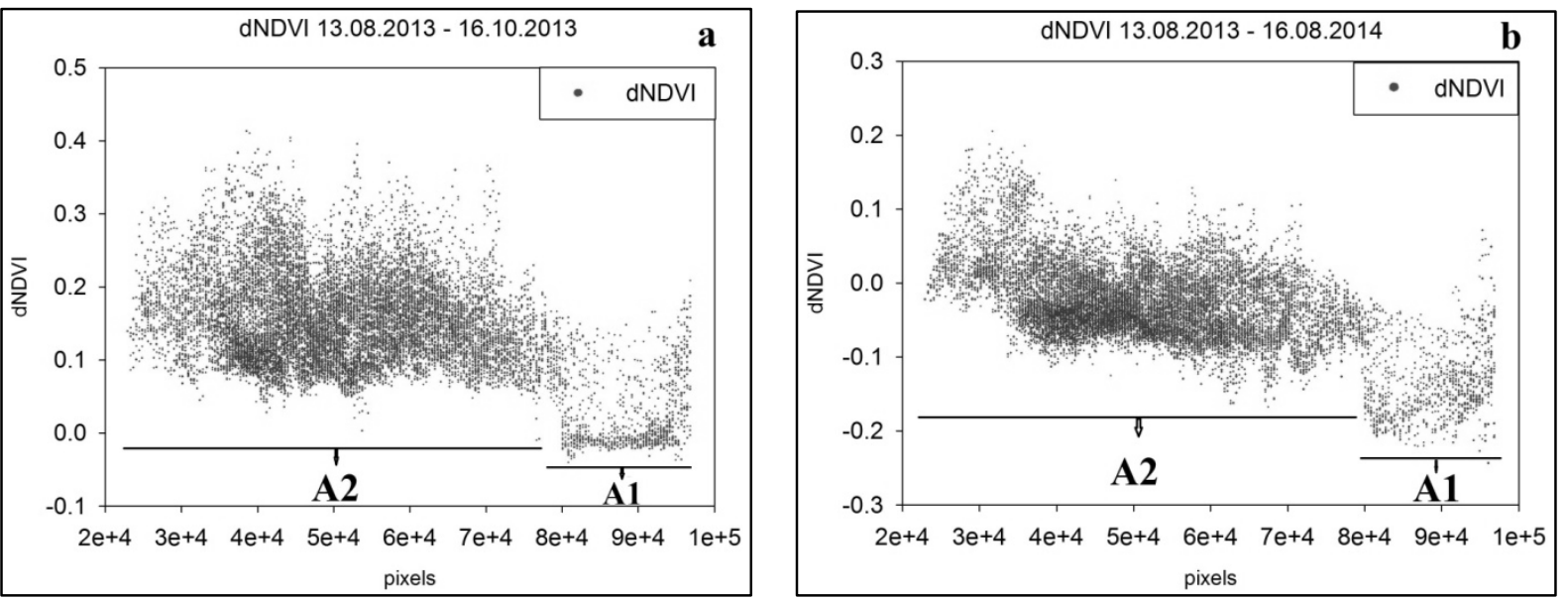

Fig.5. Values of dNDVI, extracted from pixels before fire (13.08.2013) compared with values two months after fire (16.10.2013) (a) and one year after fire (16.08.2014) (b).

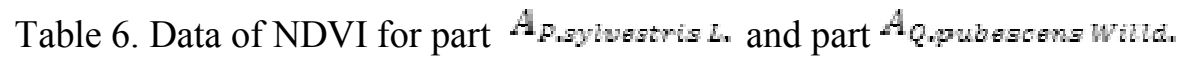

\begin{tabular}{ccccc}
\hline $\begin{array}{c}\text { Statistical } \\
\text { parameters }\end{array}$ & $\begin{array}{c}\text { NDVI Before fire } \\
/ \mathbf{1 3 . 0 8 . 2 0 1 3} /\end{array}$ & $\begin{array}{c}\text { NDVI After fire } \\
\mathbf{1 1 4 . 0 9 . 2 0 1 3 /}\end{array}$ & $\begin{array}{c}\text { NDVI After fire } \\
\mathbf{1 1 6 . 1 0 . 2 0 1 3} /\end{array}$ & $\begin{array}{c}\text { NDVI After fire } \\
/ \mathbf{1 6 . 0 8 . 2 0 1 4} /\end{array}$ \\
\hline \multicolumn{5}{c}{$\begin{array}{c}\text { Pinus } \\
\text { sylvestris L. }\end{array}$} \\
\hline Mean $( \pm \mathrm{SD})$ & $+0.367(0.038)$ & $+0.308(0.063)$ & $+0.209(0.052)$ & $\begin{array}{c}+0.262 \\
(0.054)\end{array}$ \\
\hline Min & +0.328 & +0.185 & +0.114 & +0.199 \\
\hline Max & +0.432 & +0.392 & +0.272 & +0.355 \\
\hline \multicolumn{5}{c}{ Quercus Pubescens Willd. } \\
\hline Mean $( \pm \mathrm{SD})$ & $+0.415(0.049)$ & $+0.316(0.076)$ & $+0.225(0.053)$ & +0.377 \\
\hline Min & +0.289 & +0.166 & +0.131 & +0.264 \\
\hline Max & +0.487 & +0.479 & +0.341 & +0.478 \\
\hline
\end{tabular}
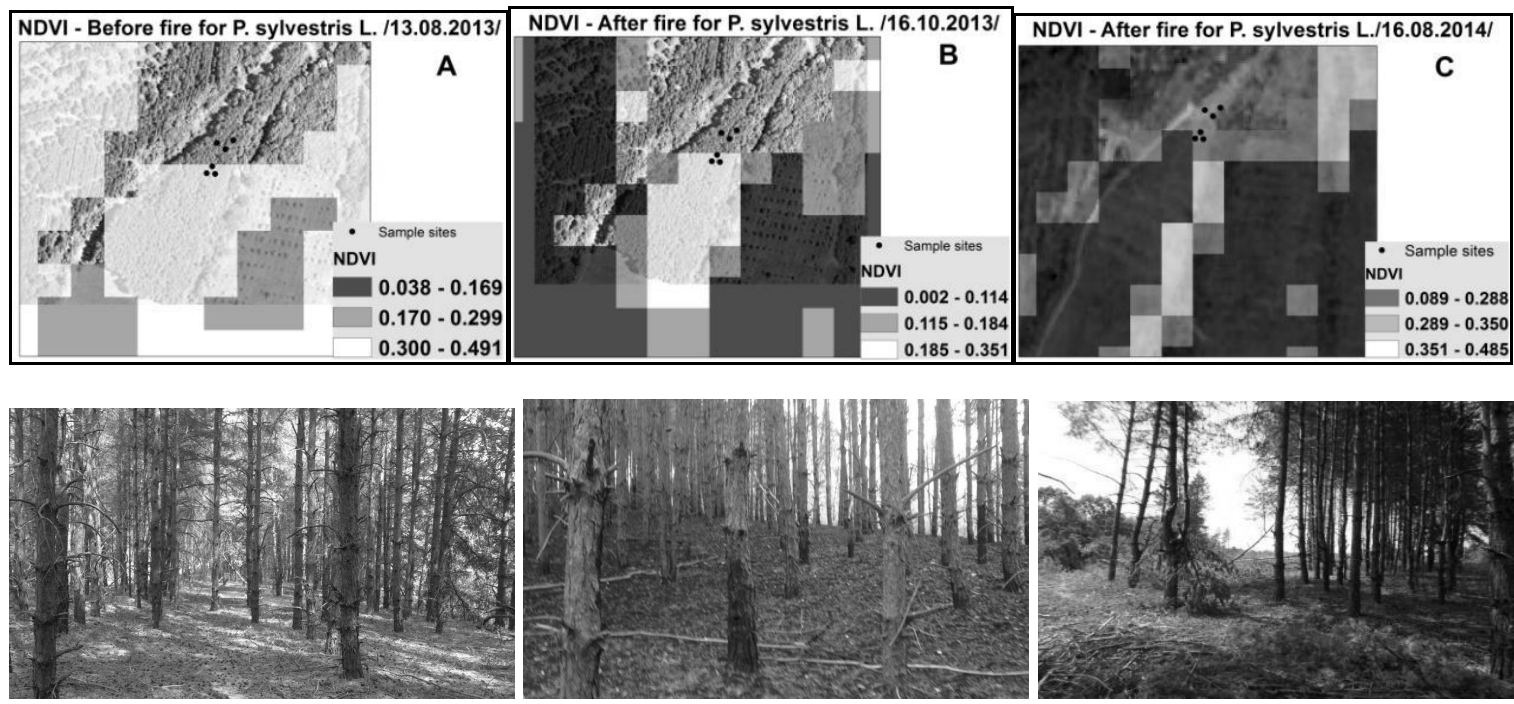

Fig. 6. NDVI and respective pictures of Pinus Sylvestris L. plantation influenced of surface fire. 
A year after fire could be seen that broadleaf tree species is not completely destroyed which corresponds to the studies which found that the temperature of fire in broadleaf tree species is lower in comparison to that of conifers due to different chemical composition of leaf /needles and bark of stand [13].

Table 7. Data of dNDVI for part $A_{\text {P.sylvestris L. and part }} A_{\text {Qmubescens wind. }}$

\begin{tabular}{cccc}
\hline Statistical & dNDVI 13.08.13 & dNDVI 13.08.13 & dNDVI 13.08.13 - \\
parameters & $\mathbf{- ~ 1 4 . 0 9 . 1 3}$ & $\mathbf{- 1 6 . 1 0 . 1 3}$ & $\mathbf{1 6 . 0 8 . 1 4}$ \\
\hline \multicolumn{4}{c}{ Pinus sylvestris L. } \\
\hline \multirow{2}{*}{ Mean $( \pm$ SD) } & +0.059 & +0.158 & +0.105 \\
& $(0.050)$ & $(0.041)$ & $(0.041)$ \\
\hline Min & 0.000 & +0.104 & +0.030 \\
\hline Max & +0.159 & +0.221 \\
\hline \multicolumn{4}{c}{ Quercus Pubescens Willd. } \\
\hline \multirow{2}{*}{ Mean $( \pm$ SD) } & +0.098 & +0.190 \\
\hline Min & $(0.053)$ & $(0.038)$ & +0.154 \\
\hline Max & +0.006 & +0.124 & +0.038 \\
\hline
\end{tabular}

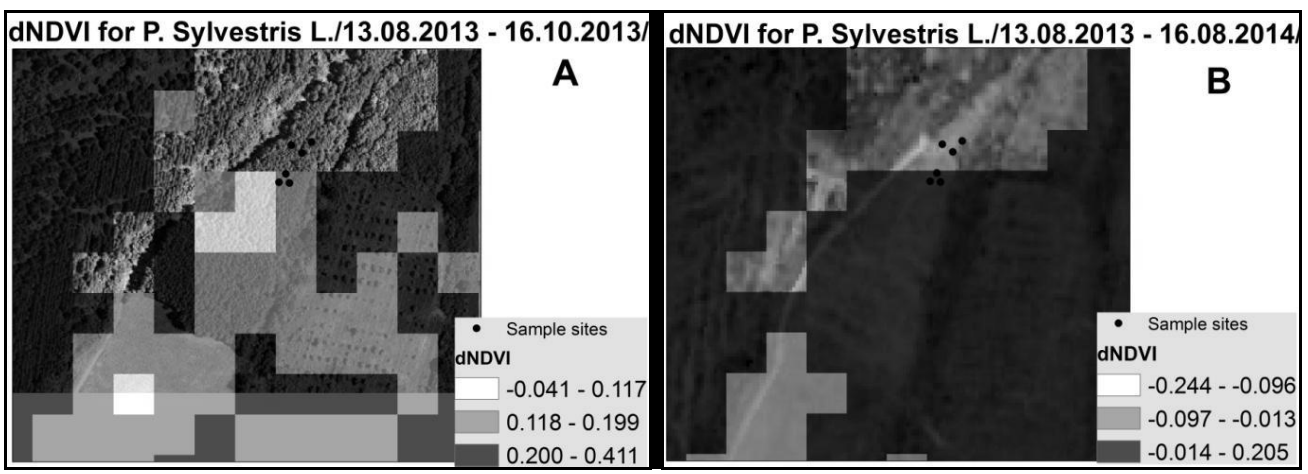

Fig. 7. d dNDVI pixels of Pinus Sylvestris L. plantation.
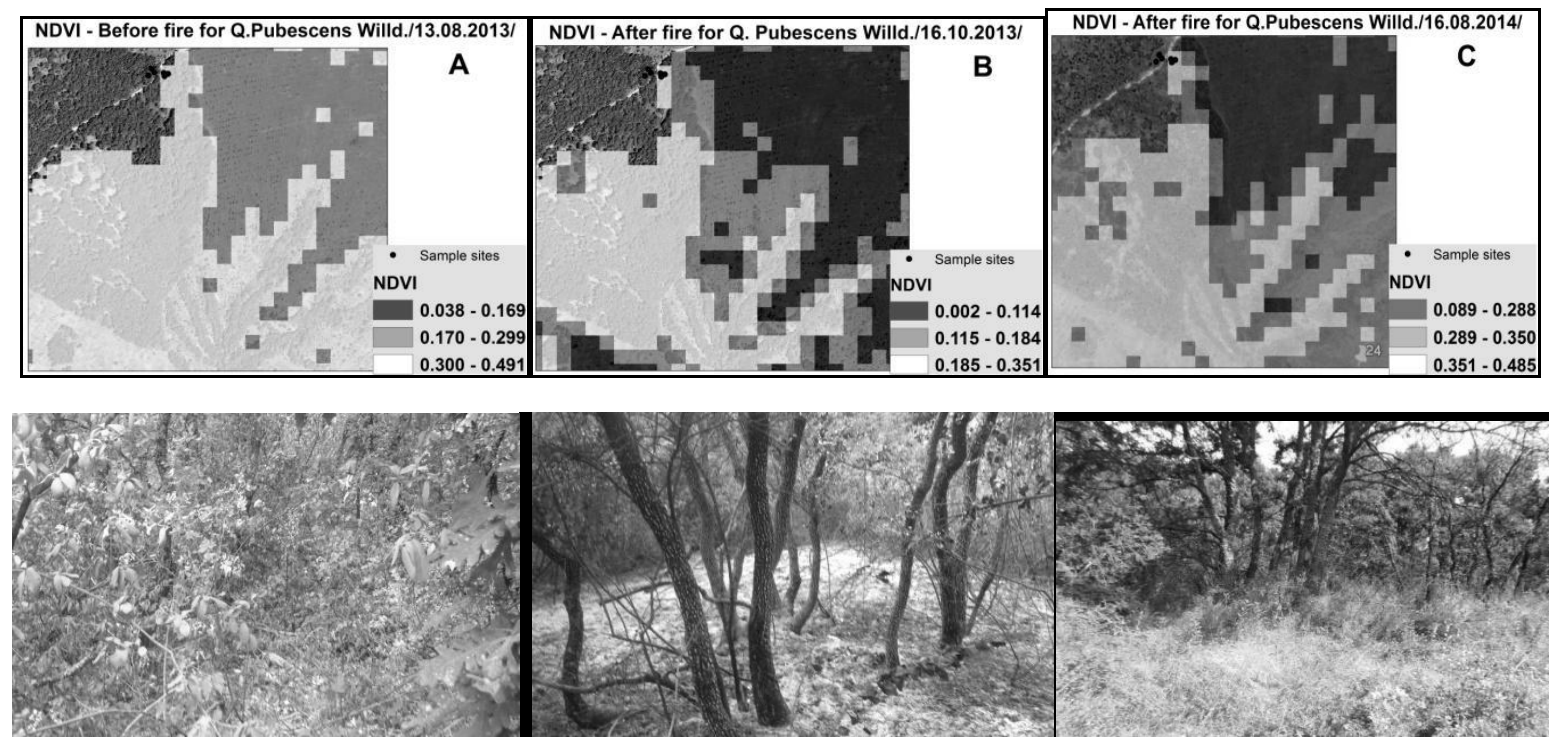

Fig. 8. NDVI and respective pictures of Quercus pubescensWilld. tands influenced by surface fire.

The first picture has taken from unaffected part of oak stand. Second picture - from fire affected area six day after surface fire. The third was taken a year after fire. 


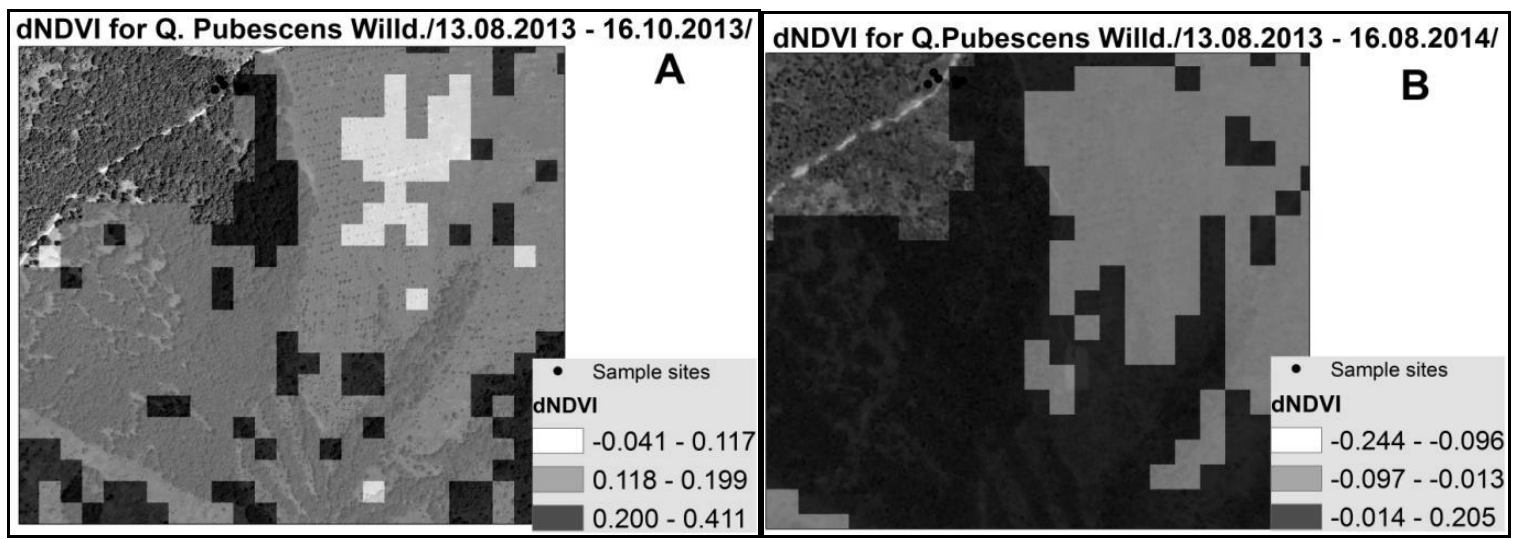

Fig. 9. dNDVI pixels of Quercus pubescensWilld. plantation.

\section{CONCLUSIONS}

The mean values of NDVI of fire affected area of FSE "Svilengrad" is $+0.124(0.048)$, while for not disturb forests it varies from $0.42-0.44$.

NDVI are changed significantly in fire affected area depending on vegetation cover and type of fire. This index also is very sensitive to changes during time after fire occurrence. One year after fire occurrence the NDVI values increased to +0.305 (0.048) for wall studied area.

Our results show that through dNDVI could be distinguish the recovery rates of the fire affected areas with different tree species.

\section{References}

1. Perez B. and J.M. Moreno, Methods for quantifying fire severity in shrubland-fires, Plant Ecology 139, 1998, 91-101.

2. White J.D., K. C. Ryan, C.C. Key and S.W. Running, Remote sensing of forest fire severity and vegetation recovery, International Journal of Wildland Fire, 6 (3), 1996, 125-136.

3. Velizarova E., K. Yorova and Al. Tashev, Investigations on some characteristics of forest soils affected by fire under plantations of Austrian pine (Pinus nigra Arn.) - I. Physical characteristic, Forest science, No.1/2, 2001, 29-34.

4. Velizarova E., R. Nedkov, I. Molla, M. Zaharinova and B. Malcheva, Soil organic matter changes in result of forest fires in Vitosha mountain, Forestry ideas, vol.20, №2(48), 2014, 35-43.

5. Neary D.G., C.C. Klopatek, L.F. DeBano and P.F. Ffolliott, Fire effects on belowground sustainability: a review and synthesis, Forest Ecology and Management Vol.122, 1999, 51-71.
6. DeBano L.F., S.M. Savage and D.A. Hamilton, The transfer of heat and hydrophobic substances during burning. Journal of the Soil Science Society of America, Vol.40, 1977, 779-782.

7. Thomas P.A. and R.W. Wein, The influence of shelter and the hypothetical effect of fire severity on the postfire establishment of conifers from seed, Canadian Journal of Forest Research, 15, 1985, 148-155.

8. Tanaka S., H. Kimura and Y. Suga, Preparation of a 1:25000 Landsat map for assessment of burnt area on Etajima Island, International Journal of Remote Sensing, Vol. 4(1), 1983, 17-31 p.

9. Levin N, Fundamentals of Remote Sensing, 1-st Hydrographic Data Management course, IMO International Maritime Academy,Trieste, Italy; Remote Sensing Laboratory, Geography Department, Tel Aviv University, Israel; GIS unit, the Society for the Protection of Nature in Israel, 1999, $114 \mathrm{p}$.

10. Gates D. M. Biophysical Ecology, Springer Advanced Texts in Life Sciences 1980, 181-267

11. Rouse J.W., R.H. Haas, J.A. Schell and D.W. Deering, Monitoring Vegetation Systems in the Great Plains with ERTS, Proceedings of Third Earth Resources Technology Satellite-1 Symposium, Greenbelt, MD, USA, 1973, 309-317.

12. Tucker C.J., Red and Photographic Infrared Linear Combinations for MonitoringVegetation, Remote Sensing of Environment, 8, 1979, 127-150. doi: http://dx.doi.org/10.1016/0034-4257(79)90013-0.

13. Petrin St., E. Velizarova, P. Tsekova, I. Valchev, S. Nenkova, T. Stankova, M. Glushkova and D. Dimitrov. 2014. Plant's fuel chemical specifity of the main bulgarian forest types. In Book of abstracts of the Eighth National Conference on Chemistry "Chemistry for Sustainable Development" 26 -27 June 2014, Sofia, Bulgaria, 58 


\title{
ОЦЕНКА НА СИЛАТА НА ПОЖАРА ЧРЕЗ ИЗПОЛЗВАНЕ НА NDVI , ПОЛУЧЕН ОТ LANDSAТ ТМ / ЕТМ ИЗОБРАЖЕНИЯ И ДАННИ ЗА TEPEHA
}

\author{
Ибрахим Молла, Румен Недков, Емилия Велизарова, Мариана Захаринова
}

\begin{abstract}
Резюме. Влиянието на горските пожари върху растителността и почвата зависи от силата на пожара и времето на въздействие. Силата на пожара обединява физичните, химичните и биологични промени, настьпващи в екосистемите като следствие на влиянието на пожара.

Целта на настоящото проучване е да се изследва силата на горския пожар върху растителната покривка от района на община Свиленград, използвайки NDVI преди и след пожар, получени от Landsat 8 TM / ETM изображения. Сравнени са данните от NDVI и тези, получени от теренни изследвания. Резултатите показват, че NDVI са се променили значително в засегнатите от пожари райони в зависимост от растителната покривка и вида на пожара. Също така, NDVI индексът е много чувствителна към промени в зависимост от времето, което е минало след пожара. Една година след възникване на пожар, стойностите NDVI са се увеличили до +0,305 $(0,048)$ за целия изследван район. Чрез dNDVI може да се направи разграничение на времето за възстановяване на засегнатите от пожар райони в зависимост от дървесния вид.
\end{abstract}

Ключови думи: сила на пожара, Рдопи, NDVI (Нормализиран Разликов Растителен индес), дървесни видове

\section{Ибрахим Молла}

Институт за гората - БАН

бул. Кл. Охридски 132

1756 София, България

e-mail: mollata@abv.bg

\section{Емилия Велизарова}

Институт за гората - БАН

Бул. Кл. Охридски 132

1756 София, България

e-mail: velizars@abv.bg

\section{Мариана Захаринова}

Институт за космически изследвания и технологии - БАН

ул. Акад. Г. Бончев, бл.1

София 1113

e-mail: marianaz@space.bas.bg

\author{
Ibrahim Molla \\ Forest Research Institute - \\ Bulgarian Academy of Sciences \\ 132 St.K. Ohridski Blvd. \\ 1756 Sofia, Bulgaria \\ e-mail: mollata@abv.bg \\ Emiliya Velizarova \\ Forest Research Institute - \\ Bulgarian Academy of Sciences \\ 132 St.K. Ohridski Blvd. \\ 1756 Sofia, Bulgaria \\ e-mail: velizars@abv.bg \\ Mariana Zaharinova \\ Space Research and Technology Institute - \\ Bulgarian Academy of Sciences \\ Acad. Georgi Bonchev Str., B1.1 \\ Sofia 1113, Bulgaria \\ e-mail: marianaz@space.bas.bg
}

